\title{
The Forgotten Ganglion: Ganglion Sublinguale
}

\begin{abstract}
Birsen Ozyurt
\section{ABSTRACT}

This study is aimed to remind the presence of ganglion sublinguale. Currently, 4 parasympathetic ganglion have been mentioned in head and neck region. Although contemporary anatomy textbooks report the ganglion submandibulare, the ganglion sublinguale has not been described in these texts. However, the ganglion sublinguale was reported by earlier researchers. Recently, Takezawa and Kageyama showed a seperate sublingual ganglion, related to the sublingual gland [1]. This information was supported by descriptions in $19^{\text {th }}$ century anatomy textbooks. A thorough understanding of the ganglion sublinguale is very important for anatomy education and oral surgical procedures.
\end{abstract}

Keywords: Anatomy education, ganglion submandibulare, ganglion sublinguale, glandula sublinguale, parasympathetic innervation.
Submitted : October 29, 2021

Published : January 25, 2022

ISSN: $2593-8339$

DOI: $10.24018 /$ ejmed.2022.4.1.1085

B. Ozyurt*

Tokat Gaziosmanpasa University, Faculty of Medicine, Department of Anatomy, Tokat, Turkey.

(e-mail: mdbirsen@hotmail.com)

*Corresponding Author

\section{INTRODUCTION}

Some of the anatomical descriptions that had been made in the $19^{\text {th }}$ century had been forgotten. One of these topics is sublingual ganglion. Contemporary textbooks define postganglionic parasympathetic innnervation of sublingual gland as; preganglionic parasympathetic fibres are supplied by fibres from neurons in the superior salivatory nucleus of the facial nerve. These fibres together with taste fibres travel within a branch of the facial nerve, the chorda tympani. The chorda tympani then join the lingual nerve to reach the submandibular ganglion. These parasympathetic fibres synapse in the submandibular ganglion. From the submandibular ganglion, postganglionic parasympathetic fibres continue to the submandibular and sublingual glands. These fibres provide secretemotor innervation to the submandibular and sublingual salivary glands [2].

At presents, it is mentioned that there are four parasympathetic ganglia located within the head. These ganglia are otic ganglion, pterygopalatine ganglion, ciliary ganglion, submandibular ganglion. The submandibular ganglion is known as submaxillary ganglion in older texts [3]. However, no explanation has been defined about the sublingual ganglion.

This paper reviews available relevant English language article of the ganglion sublinguale. Also, it was used to identify earlier relevant works. It is important for both researchers and clinicians to obtain comprehensive and available information about the sublingual ganglion of the nature and of the anatomical variation.

\section{LITERATURE}

The sublingual ganglion is not mentioned in nowadays. However, the ganglion sublinguale was reported by earlier researchers. The sublingual ganglion was first identified by Phillippe Frederic Blandin (1798-1849) in 1849. He described as "The sublingual or Blandin's ganglion is situated on the branch of nerves going to the sublingual gland. This collection of nerves may be only a plexus or a ganglion. It should have a similar connection with the submaxillary ganglion" [4].

In the same time period Edinburgh Medical and Surgical Journal (1848) was mentioned as; "A small ganglion has been found by Blandin in the sublingual gland. When present, its composition would probably be precisely similar to that of the preceding. The filaments of chorda tympani, which pass on without entering the submaxillary ganglion, would convey the same constiuent filaments to the sublingual ganglion; the gustatory nerve would supply the rest" [5].

Huber (1896) described as; First of all, it is worth noting that it was wrong to mention a submaxillary ganglion in the sense generally used, because, as Langley showed, a large number of ganglion cell groups are located in chorda-lingual triangles. The so-called submaxillary ganglion is only one, perhaps the largest of these groups. He also noted that these ganglion cells have no relation to the part of the chorda tympani that goes to the submaxillary gland. He suggested that what has hitherto been named the submaxillary ganglion would more properly be called the sublingual ganglion [6].

In Dorland's Anatomys, the sublingual ganglion (a ganglion of nerve cells) is defined as a ganglion sometimes found in fibers passing distally from the submandibular ganglion to the lingual nerve [7].

In An Illustrated Terminologia Neuroanatomica is mentioned as "The sublingual ganglion (TNA Latin: ganglion 
sublinguale; eponym: ganglion of Mayer) is a variant parasympathetic ganglion of the facial nerve and postganglionic fibers innervate the sublingual gland" [8].

Zeren described as; 5 paired ganglia supply all parasympathetic innervation to the head and neck. Four and 5.ganglions are ganglion submandibulare and ganglion sublinguale. These ganglia are near the saliva glands of the same name. The ganglion submandibulare is between the nervus lingualis and the upper edge of the glandula submandibulare. The ganglion sublinguale is on the outer side of the secretory gland and it is on the path of $\mathrm{n}$. lingualis. These ganglions receive their parasympathetic strands from the chorda tympani and their sympathetic fibres from the nearby periphery of arteries as well. Preganglionic parasympathetic fibres from the nucleus salivatorius superior via before $n$. intermedius and then the chorda tympani and nervus lingualis, which synapse at these ganglions [9].

Currently, Takezawa and Kageyama have mentioned a seperate ganglion, associated with the sublingual gland. The sublingual ganglion is peripheral to the ipsilateral submandibular ganglion. They confirmed a different ganglion that was not the ganglion submandibulare in their significant study. In their study was demonstrated that the branches distributed in the submandibular gland come from the ganglion submandibulare. However, the branches distributed in the glandula sublinguale come from both the submandibular and sublingual ganglia. They also confirmed that the ganglion located on the side of the sublingual gland appears to be the relay point for the primary contact between the preganglionic and postganglionic fibers of the sublingual gland. Therefore, they named this ganglion as sublinguale ganglion, since most of its branches are distributed in the glandula sublinguale. They also claimed that the ganglion sublinguale seem to be a transition point for the parasympathetic nerve in the small salivary glands [1]. This study was cited in another study investigating the variations of the lingual nerve. Recent study shows that there are many variations in the human lingual nerve [10].

In another previous study was mentioned that a superior salivary nucleus, a root pterygopalatine, submandibular, sublingual and auricular (in man) parasympathetic ganglia of the head peripheral branche [11].

In other hand there have more animal study than human researches about this topic. It was demonstrated that the presence of small ganglia in the connective tissue along the sublingual salivary gland in rats [12]. In another study performed on cats, the sublingual ganglion is mentioned, as well as submandibular ganglion [13]. Furthermore, Sato\&Ishii provided some evidence that differences in control of parasympathetic vasodilation between submandibular and sublingual glands in the rat [14].

\section{Conclusion}

We didn't know such a ganglion present because of there is no sublingual ganglion in contemporary texts. Essentially, it has been showed the ganglion sublinguale in Sobotta [15]. However, no explanation has been defined about the sublingual ganglion. Although there are published papers in the literature, there are some limitations. A limitation of studies is small sample sizes. Other limitation is that there may be post-mortem changes in the cadavers' tissues. Another factor limiting the studies is the difference in the techniques used in cadaver dissection.

A thorough understanding of the presence of ganglion sublinguale is very important for preventing disorders related this region, for clinicians who perform surgical procedures. Is sublingual ganglion a variation, how is it related the mylohyoid nerve and the lingual nerve, where do the preganglionic parasympathetic fibres come from? Many many questions about this topic can be asked.

Furthermore, this information would be changed in anatomy education. For example, 5 parasympathetic ganglions would be mentioned in the head region. Besides determining the presence of the ganglion sublinguale, we will need to discuss how the parasympathetic effect is in this ganglion. Further studies on the mechanisms underlying the parasympathetic innervation of submandibular and sublingual glands is needed. These findings will provide a better understanding of salivary secretion in salivary glands. Hopefully, we can create an awareness in this area. Also, this shows our respect for past anatomists.

\section{REFERENCES}

[1] Takezawa K, Kageyama I. A nerve analysis on the morphology of the lingual nerve. Anat Sci Int. 2015; 90: 298-302.

[2] Wiliams PL, Warwick R, Dyson M, Bannister LH. Gray's Anatomy. 2005; Edinburgh London.

[3] Wikipedia.org. Submandibular ganglion [Internet]. 2021 [updated 2022]. Available from: https:// en.wikipedia.org/wiki/Submandibular ganglion

[4] Robinson B. The abdominal and pelvic brain. Betz. 1907.

[5] Edinburgh Medical and Surgical Journal. 1848; 70.

[6] Huber GC. Observations on the innervation of the sublingual and submaxillary glands. J. Exp Med. 1896; 1: 281-294.

[7] Drake R, Vogl AW, Mitchell AW. Dorland's/Gray's Pocket Atlas of Anatomy E-Book. Elsevier Health Sciences. 2008.

[8] ten Donkelaar HJ, Kachlik D, Tubbs RS. An Illustrated Terminologia Neuroanatomica, Springer International Publishing, 2018.

[9] Zeren Z. Sistematik Insan Anatomisi. 1971; Ekim Yayınları.

[10] Ghabriel M, Takezawa K, Townsend G. The lingual nerve: overview and new insights into anatomical variability based on fine dissection using human cadavers. Odontology. 2019; 107: 1-9.

[11] Lobko PI, Khil'kevich SI. The intermediate nerve system. Comparative study. Morphplogia. 1992; 102(5): 42-50.

[12] NG YK, Wong WC, Ling EA. The intraglandular submandibular ganglion of postnatal and adult rats I. 1992; A light and electron microscope study. J.Anat.180: 305-314

[13] Gibbins IL, Brayden JE, Bevan JA. Distribution and origins of VIPimmunoreactive nerves in the cephalic circulation of the cat. Peptides. 1985; 5(2): 209-212.

[14] Sato T, Ishii H. Differences in control of parasympathetic vasodilation between submandibular and sublingual glands in the rat. Am J Physiol Regul Integr Comp Physiol. 2015; 309: R1432-R1438.

[15] Waschke J, Böckers TM, Paulsen F. (Eds.). Sobotta Lehrbuch Anatomie. Elsevier Health Sciences. 2019. 